\title{
HUBUNGAN KARAKTERISTIK INDIVIDU DENGAN KEJADIAN HIPERTENSI PADA PASIEN DI KLINIK RAWAT INAP SUHERMAN PERIODE JANUARI SAMPAI AGUSTUS 2012
}

\author{
NOVITA NURAINI *)
}

\begin{abstract}
ABSTRAK
Hipertensi merupakan salah satu masalah kesehatan masyarakat yang utama di Indonesia. Tekanan darah tinggi (Hipertensi) adalah suatu peningkatan tekanan darah di dalam arteri yang mengakibatkan suplai oksigen dan nutrisi ke organ target tidak optimal sehingga dapat menyebabkan peningkatan resiko terhadap penyakit stroke, gagal ginjal, dan serangan jantung. Faktor resiko hipertensi bermacam-macam diantaranya karakteristik individu dan gaya hidup. Segala kegiatan kesehatan sebagai sarana untuk promosi kesehatan dalam rangka pencegahan penyakit hipertensi dan usaha mengontrol penderita hipertensi sedang banyak dilakukan. Hal ini bertujuan menurunkan angka kejadian hipertensi serta mencegah komplikasi pada penderita hipertensi. Berdasarkan data kunjungan rawat jalan klinik rawat inap Suherman pada tahun 2012 hipertensi selalu termasuk salah satu dari sepuluh penyakit terbanyak yang terdiagnosis setiap bulannya. Penelitian ini bertujuan untuk mengetahui hubungan antara karakteristik individu dengan kejadian hipertensi di klinik rawat inap Suherman periode Januari-Agustus 2012. Penelitian ini merupakan penelitian deskriptif analitik yang menggunakan desain cross sectional survey. Objek penelitian ini adalah semua pasien yang berkunjung ke klinik dan terdiagnosis hipertensi selama periode JanuariAgustus 2012. Sampel penelitian berjumlah 30 orang yang diambil secara purposive sampling. Analisis dilakukan dengan uji korelasi .Hasil penelitian berupa data karakteristik individu pasien hipertensi, berdasarkan usia, jenis kelamin, berat badan, dan kebiasaan merokok serta hasil analisis hubungan karakteristik individu dengan kejadian hipertensi pada pasien yang berobat di klinik rawat inap suherman.

Hasil penelitian yaitu mayoritas penderitahipertensiberusia $\geq 45 \operatorname{tahun}(90 \%)$, berjenis kelamin wanita $(76,7 \%)$, memiliki riwayat merokok (76,7\%), dan memiliki berat badan lebih dari normal (90\%). Terdapathubunganyangbermaknaantarausiadenganpenderitahipertensidiklinik rawat inap suherman. Terdapathubunganyangbermaknaantarajeniskelamindenganpenderita hipertensidiklinik rawat inap suherman. Terdapatnyahubunganyangbermaknaantarakebiasaanmerokokdenganpenderita hipertensidiklinik rawat inap suherman. Terdapat hubungan yang bermakna antara berat badan dengan penderita hipertensi klinik rawat inap suherman
\end{abstract}

Kata kunci : Karakteristik individu, Hipertensi 

Novita Nuraini, Hubungan Karakteristik Individu Dengan Kejadian Hipertensi Pada Pasien Di Klinik Rawat Inap Suherman Periode Januari Sampai Agustus 2012

\section{PENDAHULUAN}

Meningkatnya prevalensi penyakit kardiovaskuler setiap tahun menjadi masalah utama di negara berkembang dan negara maju. Berdasarkan Hasil Riset Kesehatan Dasar (Riskesdas) yang dilakukan di Indonesia sebagai salah satu Negara berkembang, menunjukkan bahwa proporsi penyebab kematian tertinggi adalah penyakit tidak menular, yaitu penyakit kardiovaskuler $(31,9 \%)$ termasuk hipertensi (6,8\%) dan stroke (15,4\%). Di Amerika, diperkirakan 1 dari 4 orang dewasa menderita hipertensi. Apabila penyakit ini tidak terkontrol akan dapat menyerang target organ, dan dapat menyebabkan serangan jantung, stroke, gangguan ginjal, serta kebutaan. Dari beberapa penelitian dilaporkan bahwa penyakit hipertensi yang tidak terkontrol dapat menyebabkan peluang 7 kali lebih besar terkena stroke, 6 kali lebih besar terkena congestive heart failure, dan 3 kali lebih besar terkena serangan jantung. Menurut WHO dan The International Society of Hypertension (ISH), saat ini terdapat 600 juta penderita hipertensi di seluruh dunia, dan 3 juta di antaranya meninggal setiap tahunnya. Tujuh dari setiap 10 penderita tersebut tidak mendapatkan pengobatan secara adekuat. Penyakit hipertensi yang sering disebut sebagai the silent killer, adalah penyakit yang terjadi akibat peningkatan tekanan darah yang bisa menyebabkan berbagai komplikasi berupa kecacatan permanen dan kematian mendadak.

Faktor resiko hipertensi bervariasi berdasarkan karakteristik individu dan gaya hidup antara lain adalah faktor genetik, umur, jenis kelamin, etnis, stress, obesitas, asupan garam, dan kebiasaan merokok. Hipertensi bersifat diturunkan atau bersifat genetik. Individu dengan riwayat keluarga hipertensi mempunyai risiko dua kali lebih besar untuk menderita hipertensi daripada orang yang tidak mempunyai keluarga dengan riwayat hipertensi. Insidensi hipertensi meningkat seiring dengan pertambahan usia, dan pria memiliki risiko lebih tinggi untuk menderita hipertensi lebih awal. Hipertensi lebih banyak terjadi pada orang berkulit hitam daripada yang berkulit putih. Obesitas dapat meningkatkan kejadian hipertensi. Hal ini disebabkan lemak dapat menimbulkan sumbatan pada pembuluh darah sehingga dapat meningkatkan tekanan darah. Asupan garam yang tinggi akan menyebabkan pengeluaran berlebihan dari hormon natriouretik yang secara tidak langsung akan meningkatkan tekanan darah. Kebiasaan merokok berpengaruh dalam meningkatkan risiko hipertensi walaupun mekanisme timbulnya hipertensi belum diketahui secara pasti.
Berdasarkan daftar laporan kunjungan pasien berobat bulanan yang terdapat pada klinik rawat inap Suherman pada tahun 2012, hipertensi selalu menjadi salah satu dari 10 penyakit terbanyak pada pasien yang melakukan perawatan. Hal ini menjadi suatu agenda bagi promosi kesehatan yang akan dilakukan klinik demi tercapainya pencegahan angka kejadian penyakit hipertensi serta terkontrolnya pasien yang sudah terdiagnosis hipertensi. Berdasarkan data di atas, penulis tertarik untuk melakukan penelitian mengenai hubungan karakteristik individu dengan kejadian hipertensi pada penderita yang berobat di klinik rawat inap Suherman.

\section{METODE PENELITIAN}

a. Jenis Penelitian

Jenis penelitian ini adalah deskriptif kuantitatif dengan rancangan penelitian cross sectional, yaitu penelitian dilakukan pada suatu periode tertentu dan setiap subjek studi hanya dilakukan satu kali pengamatan selama penelitian (Budiarto, 2003)

\section{b. Lokasi dan Waktu Penelitian}

Penelitian ini dilaksanakan di Klinik Rawat Inap Suherman, jalan karimata no 23 Jember selama 3 bulan yaitu mulai bulan Oktober sampai Desember 2012.

\section{c. Populasi dan Sampel}

Penelitian dilakukan terhadap kasus pasien hipertensi yang berobat di poliklinik selama bulan Januari sampai Agustus 2012 dengan jumlah 88. Sampel yang akan diambil berasal dari populasi penelitian yang memenuhi kriteria inklusi. Besar sampel penelitian ini sejumlah 30. Pengambilan sampel pada penelitian ini dengan teknik pengambilan purposive sampling.

\section{d. Teknik Pengumpulan Data}

Teknik pengumpulan data primer dilakukan dengan survei langsung kepada responden. Dalam hal ini responden diberitahukan mengenai latar belakang, tujuan dan manfaat penelitian serta cara pengisian check list. Selanjutnya check list dan hasil observasi diisi dikumpulkan untuk diperiksa kelengkapannya. Dan dinilai 
Sedangkan data sekunder diperoleh dari penelusuran data di berkas rekam medis pasien klinik rawat inap suherman.

e. Variabel penelitian

1. Variabel independen: umur, jenis kelamin, kebiasaan merokok, berat badan

2. Variabel dependen: hipertensi

\section{f. Tahap - Tahap Penelitian}

Adapun tahap - tahap penelitian yaitu :

1. Tentukan besar populasi pasien hipertensi di klinik suherman periode januari sampai agustus 2012

2. Tentukan besar sampel yang akan diambil

3. Pengambilan data sekunder di unit rekam medis pasien

4. Pengambilan data primer dengan metode survei langsung dan menggunakan check list

5. Pengumpulan check list
6. Penghitungan skor

7. Pengolahan data

g. Pengolahan Data

Untuk mendapatkan hasil penelitian, maka pengolahan data dilakukan melalui pendistribusian sampel berdasarkan karakteristik sample dan pengujian terhadap hipotesis dengan chi square

\section{HASIL DAN PEMBAHASAN}

\subsection{GambaranKarakteristikResponden}

Berdasarkan hasil observasi dari berkas rekam medis pasien dan pengisian lembar check list didapatkan databerupa gambaran karakteristik responden berdasarkan jenis kelamin, usia, riwayat merokok dan berat badan.

\subsubsection{Jenis Kelamin}

JENIS KELAMIN

\begin{tabular}{|ll|c|c|c|l|}
\hline & & & & Cumulative \\
& & Frequency & Percent & Valid Percent & Percent \\
\hline Valid & L & 7 & 23.3 & 23.3 & 23.3 \\
& P & 23 & 76.7 & 76.7 & 100.0 \\
& Total & 30 & 100.0 & 100.0 & \\
\hline
\end{tabular}

Tabel4.1DistribusiFrekuensiRespondenMenurutJenisKelamin

laki-

Berdasarkan tabel 4.1 didapatkan karakteristik responden berdasarkan jenis kelamin yaitu responden

laki sebanyak 7 orang $(23,3 \%)$ dan responden perempuan sebanyak 23 orang $(76,7 \%)$. Hal ini sesuai dengan teori bahwa factor resiko hipertensi lebih besar didapatkan pada perempuan karena berhubungan secara hormonal. Namun demikian berdasarkan data mengenai angka kunjungan pasien rawat jalan di klinik suherman periode tahun 2012 didominasi oleh perempuan yaitu $>60 \%$

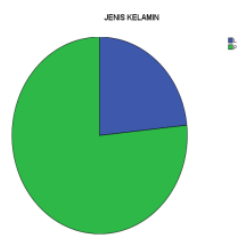

Gambar 4.1 Pie Chart Jenis Kelamin Responden 
Novita Nuraini, Hubungan Karakteristik Individu Dengan Kejadian Hipertensi Pada Pasien Di Klinik Rawat Inap Suherman Periode Januari Sampai Agustus 2012

\subsubsection{Umur UMUR}

\begin{tabular}{|rc|c|c|c|l|}
\hline & & & & & Cumulative \\
& & Frequency & Percent & Valid Percent & Percent \\
\hline Valid & $<45$ & 3 & 10.0 & 10.0 & 10.0 \\
& $>45$ & 27 & 90.0 & 90.0 & 100.0 \\
& Total & 30 & 100.0 & 100.0 & \\
\hline
\end{tabular}

Tabel4.2DistribusiFrekuensiRespondenMenurutUmur

Berdasarkan tabel 4.2 didapatkan karakteristik responden berdasarkan umur yaitu responden yang berumur kurang dari 45 tahun sebanyak 3 orang $(10 \%)$ dan yang berumur lebih dari sama dengan 45 tahun sebanyak 27 orang
(90\%). Hal ini sesuai dengan teori mengenai awal pembentukan atherosclerosis pada pembuluh darah berdasarkan penelitian sebelumnya dimulai sejak awal umur 45 tahun.

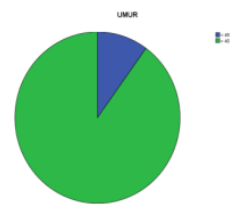

Gambar 4.2 Pie Chart Umur Responden

\subsubsection{Riwayat Merokok} RIWAYAT MEROKOK

\begin{tabular}{|c|c|c|c|c|c|}
\hline & & Frequency & Percent & Valid Percent & Cumulative Percent \\
\hline \multirow[t]{3}{*}{ Valid } & MEROKOK & 7 & 23.3 & 23.3 & 23.3 \\
\hline & TIDAK MEROKOK & 23 & 76.7 & 76.7 & 100.0 \\
\hline & Total & 30 & 100.0 & 100.0 & \\
\hline
\end{tabular}

Tabel4.3DistribusiFrekuensiRespondenMenurut Riwayat Merokok

Berdasarkan tabel 4.3 didapatkan karakteristik responden berdasarkan riwayat merokok yaitu responden yang merokok sebanyak 7 orang $(23,3 \%)$ sedangkan responden yang tidak merokok sebanyak 23 orang $(76,7 \%)$. Hal ini dapat disebabkan karena mayoritas responden berjenis kelamin perempuan, sedangkan untuk keseluruhan responden laki-laki merokok

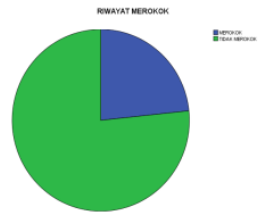

Gambar 4.3 Pie Chart Riwayat Merokok Responden 


\subsubsection{Berat Badan Berdasarkan Body Mass Index}

\begin{tabular}{|ll|l|l|l|l|}
\hline & Frequency & Percent & Valid Percent & Cumulative Percent \\
\hline Valid & $<25$ & 3 & 10.0 & 10.0 & 10.0 \\
& $>25$ & 27 & 90.0 & 90.0 & 100.0 \\
& Total & 30 & 100.0 & 100.0 & \\
\hline
\end{tabular}

Tabel4.4DistribusiFrekuensiRespondenMenurut Riwayat Merokok

Berdasarkan tabel 4.4 didapatkan karakteristik responden berdasarkan BMI yaitu jumlah responden yang memiliki BMI $<25$ sebanyak 3 orang $(10 \%)$ dan responden yang memiliki BMI > 25 sebanyak 27 orang (90\%). Hal ini menunjukkan pasien hipertensi yang memiliki berat badan berlebih merupakan mayoritas dari responden pada penelitian ini

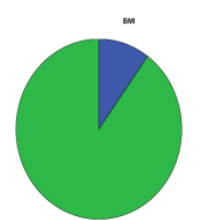

Gambar 4.4 Pie Chart BMI Responden

\subsection{AnalisisBivariat}

\subsubsection{HubunganAntaraJenisKelaminDenganKejadianHipertensi}

Tujuan dari penelitianiniadalahuntuk mengetahui adanya hubungan antarajenis kelamin dengan kejadian hipertensi pada pasien yang berobat di Klinik rawat inap suherman dengan m e l a k u k a n ujistatistikyangdisajikanpadatabelberikut:

\begin{tabular}{|l|l|}
\hline \multicolumn{1}{|l|}{ Test Statistics } \\
\hline & jenis kelamin \\
\hline Chi-Square & $8.533^{\mathrm{a}}$ \\
\hline df & 1 \\
\hline Asymp. Sig. & .003 \\
\hline
\end{tabular}

Tabel 4.5 Tabel analisis hubungan jenis kelamin dengan kejadian hipertensi

Berdasarkan analisis data,maka diperoleh gambaran bahwa penderita hipertensi mayoritas perempuan dan berdasarkan analisis bivariate maka didapatkan hubungan yang bermakna secara statistic antara usia dengan kejadian hipertensi(sig $=0,03)$. Hal ini sesuai dengan penelitian sebelumnyaolehayhani(2005)didapatkanwanitalebi hbanyakmenderitahipertensidibandingkandenganpr iayaitu51\%banding 49. aribeberapateraturdidapatka nberbagaipendapatmengenaihubunganantarajenisk elamindengankejadianhipertensi,prevalensiterjadin yahipertensipadapriasamadenganwanita.Namunwa nitaterlindungdaripenyakitkardiovaskulersebelum
menopause.Wanitayangbelummengalamimenopau sedilindungiolehhormonestrogenyangberperan dalammeningkatkankadarHDL.KadarkolesterolHD Lyangtinggimerupakan faktorpelindung dalammencegahterjadinyaprosesaterosklerosis.

\subsubsection{HubunganAntaraUmurDenganKejadianHi pertensi}

Tujuan dari penelitianiniadalahuntuk mengetahui adanya hubungan antaraumurdengan kejadian hipertensi pada pasien yang berobat di Klinik rawat inap suherman dengan e l a k u k a n ujistatistikyangdisajikanpadatabelberi kut: 
Novita Nuraini, Hubungan Karakteristik Individu Dengan Kejadian Hipertensi Pada Pasien Di Klinik Rawat Inap Suherman Periode Januari Sampai Agustus 2012

\section{Test Statistics}

\begin{tabular}{|l|l|}
\hline & umur \\
\hline Chi-Square & $19.200^{\mathrm{a}}$ \\
df & 1 \\
Asymp. Sig. & .000 \\
\hline
\end{tabular}

Tabel 4.6 Tabel analisis hubungan umur dengan kejadian hipertensi

Berdasarkan analisis data, maka diperoleh gambaran bahwa penderita hipertensi mayoritas berusia diatas 45 tahun dan berdasarkan analisis bivariate maka didapatkan hubungan yang bermakna secara statistik antara usia dengan kejadian hipertensi $(\operatorname{sig}=0,00)$.

Hasil penelitian ini sesuai dengan penelitia sebelumnya oleh Oktora (2007), didapatkan bahwa sebanyak $55,55 \%$ dari penderita hipertensi berusia diatas 45 tahun. Hal ini sesuai dengan teori yang menyatakan bahwa setelah umur 45 tahun, dinding arteri akan mengalami penebalan karena adanya penumpukan zat kolagen pada lapisan otot sehingga pembuluh darah akan berangsur-angsur menyempit dan menjadi kaku. Penyempitan dan kekakuan pembuluh darah ini mempengaruhi dari resistensi perifer sehingga menjadi salah satu penyebab peningkatan pembuluh darah.

\subsubsection{Hubungan Antara Riwayat Merokok Dengan Kejadian Hipertensi}

Tujuan dari penelitian ini adalah untuk mengetahui adanya hubungan antara kebiasaan merokok dengan kejadian hipertensi pada pasien yang berobat di klinik rawat inap suherman. Untuk mengetahui hubungan tersebut telah dilakukan uji statistik yang disajikan pada tabel berikut :

\section{Test Statistics}

\begin{tabular}{|l|l|}
\hline & riwayat merokok \\
\hline Chi-Square & $8.533^{\text {a }}$ \\
\hline Df & 1 \\
\hline Asymp. Sig. & .003 \\
\hline
\end{tabular}

Tabel 4.6 Tabel analisis hubungan riwayat merokok dengan kejadian hipertensi

Berdasarkan analisis univariat, didapatkan mayoritas penderita hipertensi memiliki kebiasaan merokok. Selanjutnya hasil ini dianalisis dengan nilai korelasi ( $\operatorname{sig}=0,03)$, yang berarti bahwa terdapat hubungan yang bermakna secara statistik antara kebiasaan merokok dengan kejadian hipertensi pada pasien yang berobat di klinik rawat inap suherman. Hasil penelitian ini sesuai dengan hasil penelitian Rayhani (2005) didapatkan $80 \%$ dari penderita hipertensi mempunyai riwayat merokok

\subsubsection{Hubungan Antara Berat Badan Dengan Kejadian Hipertensi}

Tujuan dari penelitian ini adalah untuk mengetahui adanya hubungan antara berat badan yang dapat diukur dengan BMI,yaitu bila BMI lebih dari 25 dianggap memiliki factor resikoterhadap kejadian hipertensi pada pasien yang berobat di klinik rawat inap suherman. Untuk mengetahui hubungan tersebut telah dilakukan uji statistik yang disajikan pada tabel berikut : 


\section{Test Statistics}

\begin{tabular}{|l|l|}
\hline & riwayat merokok \\
\hline Chi-Square & $8.533^{\mathrm{a}}$ \\
\hline Df & 1 \\
\hline Simornilai & .003 \\
\hline
\end{tabular}

Tabel 4.5 Tabel analisis hubungan BMI dengan kejadian hipertensi

Berdasarkan analisis univariat, didapatkan mayoritas penderita hipertensi memiliki BMI lebih dari 25 Selanjutnya hasil ini dianalisis dengan nilai korelasi $(\operatorname{sig}=0,00)$, yang berarti bahwa terdapat hubungan yang bermakna secara statistik antara BMI lebih dari 25 dengan kejadian hipertensi pada pasien yang berobat di klinik rawat inap suherman. Berat badan berlebih dikaitkan dengan peningkatan kadar kolesterol serum, sehingga akan mempermudah terjadinya aterosklerosis.

\subsubsection{Hubungan antara kebiasaan merokok dengan kejadian hipertensi pada pasien yang berobat dipoliklinik dewasa Puskesmas Bangkinang}

Berdasarkan analisis univariat, didapatkan penderita hipertensi memiliki kebiasaan merokok $\geq 15$ batang/hari. Selanjutnya hasil ini dianalisis dengan uji korelasi Spearman's rho, dengan nilai korelasi $(\mathrm{p}=0,00)$, yang berarti bahwa terdapat hubungan yang bermakna secara statistik antara kebiasaan merokok $\geq 15$ batang/hari dengan kejadian hipertensi pada pasien yang berobat di poliklinik dewasa Puskesmas Bangkinang. Nilai PAR yang diperoleh sebesar 0,50 , yang artinya sekitar $50 \%$ kejadian hipertensi dapat dicegah dengan menghilangkan faktor kebiasaan merokok. Hasil penelitian ini sesuai dengan hasil penelitian Rayhani (2005) didapatkan $80 \%$ dari penderita hipertensi mempunyai riwayat merokok. 36 Hasil ini juga didukung oleh hasil penelitian Julianty P (2001), yang menyatakan responden yang berprilaku tidak sehat (merokok, minum minuman keras dan kurang olah raga) mempunyai risiko 1,53 kali menderita hipertensi dibandingkan dengan responden yang berprilaku sehat.

\section{KESIMPULAN DAN SARAN}

\section{Kesimpulan}

1. Mayoritas penderita hipertensi berusia $\geq 45$ tahun $(90 \%)$, berjenis kelamin wanita $(76,7 \%)$, memiliki riwayat merokok $(76,7 \%)$, dan memiliki berat badan lebih dari normal (90\%)

2. Terdapat hubungan yang bermakna antara usia dengan penderita hipertensi di klinik rawat inap suherman.

3. Terdapat hubungan yang bermakna antara jenis kelamin dengan penderita hipertensi di klinik rawat inap suherman.

4. Terdapatnya hubungan yang bermakna antara kebiasaan merokok dengan penderita hipertensi di klinik rawat inap suherman.

5. Terdapat hubungan yang bermakna antara berat badan dengan penderita hipertensi klinik rawat inap suherman

\section{Saran}

1. Klinik suherman dalam menentukan sasaran untuk pelaksanaan penyuluhan kesehatan demi mengurangi angka kejadian hipertensi hendaknya lebih mengutamakan masyarakat dengan jenis kelamin wanita pada kelompok umur lebih dari sama dengan 45 tahun serta masyarakat dengan kebiasaan merokok dan berat badan berlebih.

2. Perlu dilakukan penelitian lanjutan terkait tingkat pengetahuan dan sikap kelompok resiko tinggi hipertensi setelah pelaksanaan penyuluhan di klinik rawat inap suherman. 
Novita Nuraini, Hubungan Karakteristik Individu Dengan Kejadian Hipertensi Pada Pasien Di Klinik Rawat Inap Suherman Periode Januari Sampai Agustus 2012

\section{DAFTAR PUSTAKA}

Armilawaty, Amalia H, Amirudin R. 2007. Hipertensi dan Faktor Risikonya dalam Kajian Epidemiologi. Bagian Epidemiologi FKM UNHAS

Budiarto, Eko. 2003. Metodologi Penelitian Kedokteran. EGC. Jakarta

Bowman ST et al. Clinical Research Hypertension. A Prospective Study of Cigarette Smokey And Risk of Inciden Hypertension In Bringham And Women Hospital Massachucetts, 2007.p 1-3.

Kumar V, Abbas AK, Fausto N. Hypertensive Vascular Disease. Dalam: Robn and Cotran Pathologic Basis of Disease, 7th edition.
Philadelpia: Elsevier Saunders, 2005.p 528-529. Wade, A Hwheir, D N Cameron, A. 2003. Using a Problem Detection Study (PDS) to Identify and Compare Health Care Privider and Consumer Views of Antihypertensive therapy. Journal of Human Hypertension, Jun Vol 17 Issue 6, p397.

Waspadji S dkk. Daftar Bahan Makanan Penukar. Divisi Metabolik Endokrin Departemen Ilmu Penyakit Dalam dan Instalasi Ilmu Gizi RS Cipto Mangunkusuno, Jakarta, 2004, hal.1-21.

Yogiantoro M. Hipertensi Esensial. Dalam Buku Ajar Ilmu Penyakit Dalam Jilid I Edisi ke IV. Pusat Penerbitan Departemen Ilmu Penyakit Dalam. Fakultas Kedokteran Universitas Riau. Jakarta. 2006: 610-1 


\section{ABSTRAK PENELITIAN SELANJUTNYA \\ TINGKAT PENGETAHUAN DAN SIKAP KELOMPOK RESIKO TINGGI HIPERTENSI SETELAH PELAKSANAAN PENYULUHAN DI KLINIK RAWAT INAP SUHERMAN}

LATAR BELAKANG : Klinik rawat inap suherman adalah klinik rawat inap yang memiliki program penyuluhan dalam rangka peningkatan derajat kesehatan dan penurunan agka kesakitan. Berdasarkan data kunjungan rawat jalan sampai pertengahan tahun 2012, hipertensi selalu berada di tingkat 10 besar penyakit terbanyak laporan penyakit terbanyak. Sesuai dengan hasil penelitian sebelumnya terdapat 4 faktor resiko terkait karakteristik individu yang berhubungan secara signifikan terhadap kejadian hipertensi. Hal ini dapat digunakan sebagai masukan kepada pihak klinik dalam memprioritskan peserta penyuluhan guna memberikan penyuluhan yang tepat sasaran dimana diutamakan wanita berusia lebih dari sama dengan 45 tahun, krlompok dengan kebiasaan merokok dan berat badan berlebih. Setelah dilakukan penyuluhan peneliti ingin mengetahui bagaimana tingkat pengetahuan dan sikap peserta penyuluhan serta angka kejadian hipertensi dalam 3 bulan kemudian di klinik rawat inap suherman

TUJUAN PENELITIAN : Mengidentifikasi tingkat pengetahuan dan sikap kelompok resiko tinggi hipertensi setelah pelaksanaan penyuluhan di klinik rawat inap suherman serta mengetahui angka kejadian hipertensi 3 bulan selama 3 bulan kemudian

METODOLOGI PENELITIAN :Jenis penelitian ini deskriptif kuantitatif dengan rancangan penelitian cross sectional. Penelitiandilaksanakan di klinik rawat inap suherman. Jenis sampel random sampling. Dengan penetuan jumlah sampel didapatkan sejumlah 32 orang. Data primer didapatkan dengan survei langsung dan pengisian kuesioner. Sedangkan data sekunder diperoleh dari data pasien di berkas rekam medis klinik rawat inap suherman.

KATA KUNCI : 

